\title{
Oil Shocks and Price Stability
}

\author{
Yi Wen and Luke M. Shimek
}

W hile oil prices are near record highs, the U.S. economy has yet to experience a sharp rise in inflation as it did in the 1970s and early 1980s. Why the difference?

The relationship between oil prices and the U.S. economy has gone through dramatic changes since the 1980s. Changes in the GDP deflator and the price index of total imports (which reflect domestic and traded-goods price movements, respectively) were significantly correlated with changes in oil prices during the 197383 oil crisis (see chart). In that period, the correlation between oil price changes and GDP deflator inflation was 0.4 ; the correlation between oil price changes and import price inflation was even closer, 0.9. The closer relationship of oil price changes to import price changes suggests that the share of foreign energy imports in total imports is larger than the share of oil expenditures in GDP. However, since 1984, the close relationship between oil price changes and the U.S. economy has weakened significantly: Correlation with the GDP deflator has decreased to 0.13 , while correlation with import price changes has decreased to 0.65 .

Associated with the decline in these correlations are significant reductions in price volatility. The volatility of GDP deflator inflation-measured as standard deviation from sample meanwas 0.019 during the oil crisis period and 0.0079 in the post-1984 period, a 60 percent reduction. Similarly, the standard deviation of import price changes has decreased from 0.136 to 0.037 in the post- 1984 period, a 70 percent reduction. Meanwhile, the reduction of oil price volatility has not been as dramatic, decreasing from 0.548 to 0.297 (only a 45 percent reduction).

Economists do not have a complete answer for what caused these changes, but they have offered some conjectures. Gregory Mankiw ${ }^{1}$ claims an important clue is that the economy is far more energy-efficient today than it was in the past, in part because economic activity is based more on services and less on manufacturing. For example, the energy consumption per dollar of GDP has decreased by about 50 percent today compared with the early 1970s. As a result, energy prices matter less today. According to Olivier Blanchard and Jordi Gali, ${ }^{2}$ in addition to the smaller share of oil in production, more- flexible labor markets and improvements in monetary policy have contributed to the increased price stability. In particular, decreased wage rigidities in the labor market may have helped reduce the impact of oil shocks on output, and the stronger commitment by central banks to maintaining a low and stable rate of inflation may have ameliorated the effect of oil price increases on inflation.

According to Federal Reserve Bank of St. Louis President William Poole, "Market adjustments have been the hero in preventing energy price increases over the past four years from disrupting economic growth." While higher gas prices have put a strain on consumers, "there is no energy crisis and households and firms are adjusting in a sensible way to price increases." ${ }^{3}$

In sum, better adjustments and responses to oil price shocks by both the government and the private sector have been the essential contributors to price stability.
1 Mankiw, Gregory. "Where Have All the Oil Shocks Gone?" http://gregmankiw.blogspot.com/2007/10/where-have-all-oil-shocks-gone.html (accessed 10/31/2007).

2 Blanchard, Olivier and Gali, Jordi. "The Macroeconomic Effects of Oil Shocks: Why Are the 2000s So Different from the 1970s?” NBER Working Paper 13368, National Bureau of Economic Research, 2007.

3 See two speeches by William Poole: "Energy and the U.S. Macro Economy" (http://stlouisfed.org/news/speeches/2007/07_24_07.html) and "Energy Prices and the U.S. Business Cycle” (http://stlouisfed.org/news/speeches/2007/03_02_07.html).

Views expressed do not necessarily reflect official positions of the Federal Reserve System.

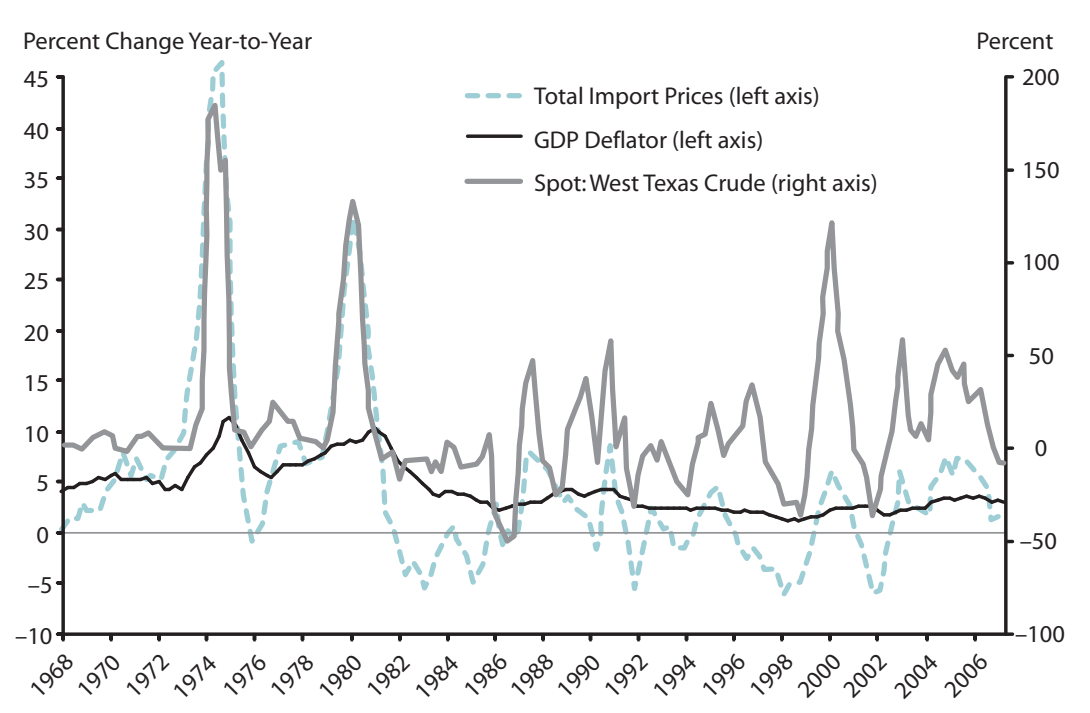

SOURCE: Haver Analytics/BEA/Wall Street Journal. 